\title{
Erratum to: First record of the glass octopus Vitreledonella richardi (Cephalopoda: Vitreledonellidae) from the Arabian Sea
}

\author{
K. K. Sajikumar ${ }^{*}$, V. Venkatesan, R. Jeyabaskaran, Abbas Muhammed and K. S. Mohamed
}

\section{Erratum}

The original version of this article (Sajikumar et al. 2016) unfortunately contained an error within the abstract conclusion.

This has been corrected to: Conclusion: Record of this rare octopus, from Arabian Sea is an addition to the cephalopod fauna of India.

Received: 21 July 2016 Accepted: 5 August 2016

Published online: 15 August 2016

\section{Reference}

Sajikumar, et al. Marine Biodiversity Records. 2016;9:53. doi:10.1186/541200-016-0041-6.

* Correspondence: kksajikumar@yahoo.co.in

Central Marine Fisheries Research Institute (CMFRI), Post box No.1608,

Ernakulam North, Kerala, India

\footnotetext{
Submit your next manuscript to BioMed Central and we will help you at every step:

- We accept pre-submission inquiries

- Our selector tool helps you to find the most relevant journal

- We provide round the clock customer support

- Convenient online submission

- Thorough peer review

- Inclusion in PubMed and all major indexing services

- Maximum visibility for your research
}

Submit your manuscript at

www.biomedcentral.com/submit 